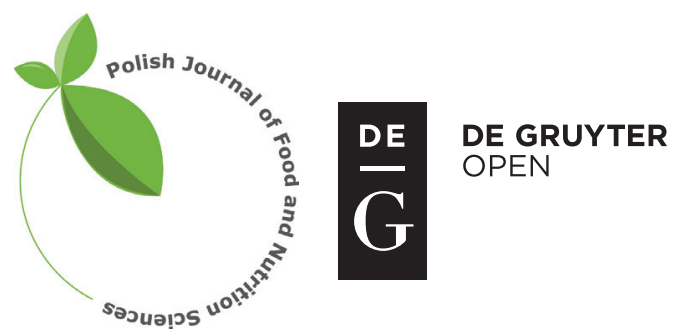

Pol. J. Food Nutr. Sci., 2018, Vol. 68, No. 4, pp. 367-375

DOI: $10.2478 /$ pjfns-2018-0006 http://journal.pan.olsztyn.pl

Original research article

Section: Food Quality and Functionality

\title{
Physico-Chemical Characteristics and Sensory Quality of Dry Fermented Sausages with Flaxseed Oil Preparations
}

\author{
Slaviša Stajić1 ${ }^{*}$, Nikola Stanišic ${ }^{2}$, Steva Levic ${ }^{3}$, Vladimir Tomović, \\ Slobodan Lilićs, Danijela Vranićs, Marija Jokanović, Dušan Živković ${ }^{1}$ \\ ${ }^{1}$ University of Belgrade, Faculty of Agriculture, Department of Animal Source Food Technology, \\ Nemanjina 6, 11080, Belgrade, Serbia \\ ${ }^{2}$ Institute for Animal Husbandry, Autoput 16, P. Box 23, 11080, Belgrade-Zemun, Serbia \\ ${ }^{3}$ University of Belgrade, Faculty of Agriculture, Department of Food Technology and Biochemistry, \\ Nemanjina 6, 11080, Belgrade, Serbia \\ ${ }^{4}$ University of Novi Sad, Faculty of Technology, Bulevar Cara Lazara 1, 21000 Novi Sad, Serbia \\ ${ }^{5}$ Institute of Meat Hygiene and Technology, Kaćanskog 13, 11000 Belgrade, Serbia
}

Key words: fermented sausages, flaxseed oil, pre-treatment, internal colour, instrumental texture, sensory analysis

The aim of this study was to determine the extent of changes in physico-chemical and sensory properties of dry fermented sausages where pork backfat was partly replaced by flaxseed oil used as liquid (FXL), after encapsulation (FXE), and pre-emulsified with alginate (FXA) and soy protein isolate (FXI). During production and storage, similar $\mathrm{pH}$ values of all products were observed. FXL sausages had significantly lower $(\mathrm{p}<0.05)$ weight loss which led to significantly higher moisture content, significantly lower fat content, hardness and chewiness. Also, FXL sausages had the lowest grades in terms of sensory attributes, such as colour, odour, taste, texture and overall acceptability. Flaxseed oil preparations affected the parameters of instrumental colour analysis of sausages. All modified products had significantly higher yellowness (relative to control) and FXI sausages relative to other modified products. Regarding consumer sensory evaluation, FXA sausages stood out among modified products because all other modified products had significantly lower grades relative to control. The thirty-day storage period did not lead to significant changes ( $p>0.05$ ) in any of the observed sensory characteristics.

\section{INTRODUCTION}

In the last third of the XX century, nutritionists recognised that some food components (sodium, sugars, fat/saturated fatty acids), if consumed in certain quantities, can affect health negatively [Doyon \& Labrecque, 2008]. Conversely, some other components (antioxidants, $n-3$ fatty acids, minerals, vitamins) can help prevent or treat certain diseases [Decker \& Park, 2010]. Hence the question arose as to how to modify certain foods/food products to reduce (or eliminate) the unwanted and add (or increase) the preferred components. Thus in the 1980s the term "functional food" was created in Japan and from there it spread across the globe [Siró et al., 2008]. As meat is a valuable source of many components with a positive effect on health, such as proteins, conjugated linoleic acid (CLA), minerals (iron, zinc and selenium), vitamins (B, E), L-carnitine, carnosine, etc., it could be considered functional food without any additional processing [Olmedilla-Alonso et al., 2013]; however, it is also believed

\footnotetext{
* Corresponding Author: Tel.: +381114413272;

E-mail: stajic@agrif.bg.ac.rs (S. Stajić)
}

that natural traditional products with components positively influencing the health are not functional foods in the strict sense [Kaur \& Das, 2011]. Meat lipids, however, have poorer nutritional qualities due to the high content of saturated fatty acids (SFAs) - increased intake of meat lipids has been associated with a higher risk of cardiovascular diseases [Olmedilla-Alonso et al., 2013]. By contrast, in meat products, including fermented sausages, sensory quality and stability greatly depend on the amount of fatty tissue and its fatty acid content - fatty tissue contributes to colour, odour, taste and texture, while SFAs affect the hardness of the fatty tissue and reduce its susceptibility to oxidation.

Since the 1980s, when lower incidence of heart diseases in Greenlandic Inuits (despite their diet rich in fats and cholesterol) was explained by a high intake of $n-3$ polyunsaturated fatty acids [Trautwein, 2001], a number of research studies noted the importance of this group of fatty acids (FAs) for the prevention and treatment of various diseases [Gogus \& Smith, 2010; Zhang et al., 2010]. Flaxseed oil is a good source of $\alpha$-linolenic acid (ALA), an $n$-3 FA which can be metabolised to longer-chain $n$-3 FAs: eicosapentaenoic acid, docosapentaenoic acid, and docosahexanoic acid [Gogus \& Smith, 
2010; Trautwein, 2001]. It normally contains more than 50\% of ALA, hence its nutritive importance and use have grown over the past years, giving rise to a number of supplements containing flaxseed oil [Choo et al., 2007]. It also contains bioactive compounds - $\gamma$-tocopherol and phenolic acids and has oxidative stability [Choo et al., 2007; Teh \& Birch, 2013].

The functional properties of fermented sausages can be improved through a change in their FA profile, by replacing a part of backfat with oils rich in mono and polyunsaturated FAs (MUFAs and PUFAs, respectively), including olive, flaxseed, canola, fish, grapeseed oil [Alejandre et al., 2016; Bolumar et al., 2015; Pelser et al., 2007; Stajić et al., 2014]. To increase oxidative stability, oils can be pre-treated by pre-emulsification and encapsulation [Delgado-Pando et al., 2010; Josquin et al., 2012]. Literature data indicate that oil in a water emulsion system with soy protein isolates was the most used pre-treatment. Some newer data indicate a good potential of the gelled emulsion system as oil pretreatment [Alejandre et al., 2016; Stajić et al., 2014].

Given the significance of fatty tissue on sensory characteristics of fermented sausages, improving the fatty acid profile with oils rich in MUFAs and PUFAs is a challenge, as it requires the development of a product with better nutritional and identical or slightly altered sensory qualities.

The aim of this study was to determine the extent of changes in physico-chemical and sensory properties of dry fermented sausages where pork backfat was partly replaced by flaxseed oil used as liquid, after encapsulation and preemulsified with alginate and soy protein isolate, after production and after a 30-day refrigerated storage period.

\section{MATERIALS AND METHODS}

\section{Sausage manufacture}

The control product (CON) was made of $75 \%$ of fresh boneless pork ham and $25 \%$ of pork backfat. The other four products were made by substituting $20 \%$ of backfat with flaxseed oil prepared in different ways: product 1 (FXL) with liquid oil cooled to refrigerator temperature $\left(4-8^{\circ} \mathrm{C}\right)$, product 2
(FXA) with pre-treated oil with alginate, product 3 (FXI) with pre-emulsified (PE) oil with soy protein isolate (SPI), and product 4 (FXE) with encapsulated oil (Table 1, Figure 1). Flaxseed oil, meat and backfat were bought at a local store; meat and backfat were frozen at $-20^{\circ} \mathrm{C}$ and stored for $48 \mathrm{~h}$ before production. Sausage preparation, oil preparation, drying process, packaging and storage conditions were as described by Stajić et al. [2014]. The average diameter of encapsulated flaxseed oil of the $\mathrm{N}=30$ sample was $1161 \pm 82 \mu \mathrm{m}$, and the oil content was $401 \mathrm{~g} / \mathrm{kg}$. The mass of each batch was approximately $6 \mathrm{~kg}$, while the sausages weighed $300-360 \mathrm{~g}$. Two replicates of the experiment were carried out.

\section{Physico-chemical analysis}

Eight individual sausages from each product were weighed on the scales (Chyo, MK-2000B, Kyoto, Japan) with a $0.1 \mathrm{~g}$ precision ratio, in order to determine weight loss (expressed in $\mathrm{g} / \mathrm{kg}$ ) on production days 0 (D0), 2 (D2), 7 (D7), and 15 (D15).

Four sausages were randomly taken from each product for the analysis of proximate composition and $\mathrm{pH}$ changes.

On production days D0 (beginning of production), D15 (end of production), and D45 (end of a 30-day storage), moisture content [ISO 1442, 1997], protein content [ISO 937, 1978] and fat content [ISO 1443, 1973] were determined.

The $\mathrm{pH}$ value was measured with an $\mathrm{HI} 83141 \mathrm{pH}$-meter (Hanna Instruments, Sarmeola di Rubano, Italy) equipped with a penetration probe, on D0, D2, D7, D15, and D45.

Six sausages were taken randomly from each product for instrumental colour and texture profile analysis.

The MINOLTA Chroma Meter CR-400 (Minolta Co., Ltd., Osaka, Japan) was used to determine the CIE L*a*b* colour coordinates. The measurements were performed using an $8 \mathrm{~mm}$ aperture size, illuminant D65 and a $2^{\circ}$ standard observer angle, calibrated using a Minolta calibration plate (No. 11333090; $Y=92.9, x=0.3159 ; y=0.3322)$. Konica Minolta Color Data Software CM-S100w Spectra Magictm NX Pro QC ver. 2.0 was used to calculate chroma $\left(\mathrm{C}^{*}\right)$ and hue angle (h). Internal product colour was determined immediately after the samples were cut, and measurements were performed

TABLE 1. Recipe formulation of experimental batches.

\begin{tabular}{|c|c|c|c|c|c|}
\hline Specification & $\mathrm{CON}$ & FXL & FXA & FXI & FXE \\
\hline Pork meat (kg) & 4.50 & 4.50 & 4.50 & 4.50 & 4.50 \\
\hline Backfat $(\mathrm{kg})$ & 1.50 & 1.20 & 1.20 & 1.20 & 1.20 \\
\hline Flaxseed oil (kg) & & 0.30 & 0.30 & 0.30 & $(\approx 0.30)$ \\
\hline Alginate mixture (kg) & & l & 0.03 & / & l \\
\hline Water $(\mathrm{kg})$ & & l & 0.45 & 0.30 & $(\approx 0.38)$ \\
\hline $\mathrm{SPI}^{*}(\mathrm{~kg})$ & & l & l & 0.06 & / \\
\hline Encapsulated flaxseed oil (kg) & & / & / & / & 0.75 \\
\hline Total initial batch $(\mathrm{kg})$ & 6.00 & 6.00 & 6.48 & 6.36 & 6.45 \\
\hline Flaxseed oil in initial batch (\%) & & 5.00 & 4.63 & 4.72 & 4.65 \\
\hline
\end{tabular}

* SPI=Soy protein isolate; $\mathrm{CON}=$ Control product; $\mathrm{FXL}=$ product with liquid flaxseed oil; $\mathrm{FXA}=$ product with flaxseed oil with alginate; $\mathrm{FXI}=$ product with flaxseed oil with soy protein isolate; and FXE=product with encapsulated flaxseed oil. 


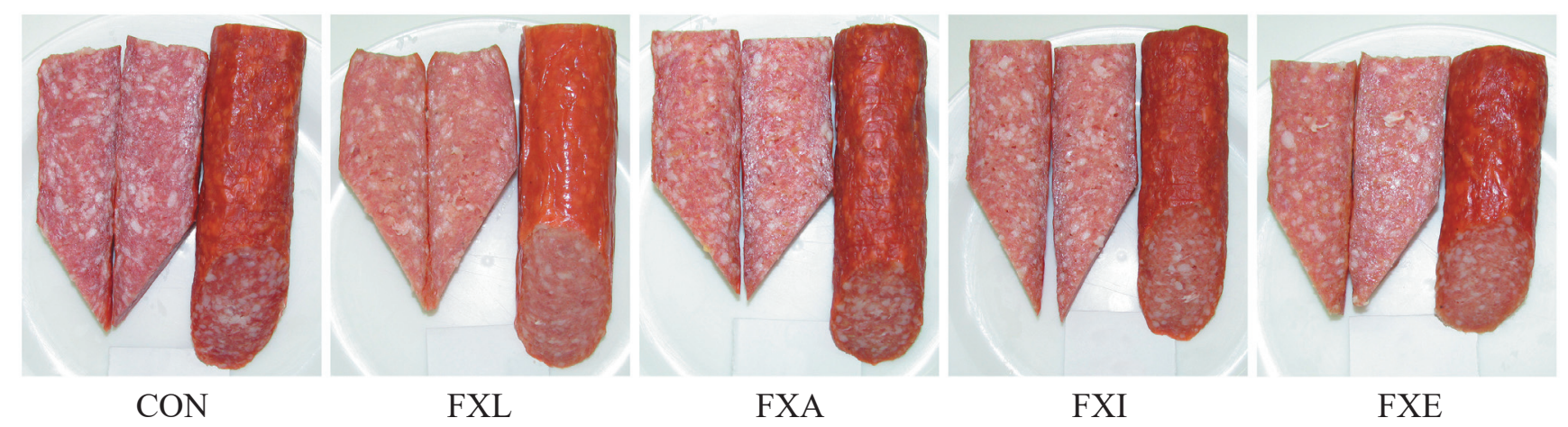

FIGURE 1. Visual appearance of modified dry fermented sausages.

$\mathrm{CON}=$ Control product; FXL= product with liquid flaxseed oil; FXA=product with flaxseed oil with alginate; FXI=product with flaxseed oil with soy protein isolate; FXE= product with encapsulated flaxseed oil

at room temperature $\left(20 \pm 2^{\circ} \mathrm{C}\right)$. Eighteen readings were taken for each product on D15 and D45. The total colour difference (relative to $\mathrm{CON}$ ) of the modified sausages $\left(\mathrm{TCD}_{\mathrm{CON}}\right)$ was determined on both D15 and D45. The total colour difference during storage $\left(\mathrm{TCD}_{\mathrm{STOR}}\right)$ was also calculated for each product. Both TCDs were calculated based on the formula of Bozkurt \& Bayram [2006] adjusted by Stajić et al. [2017]:

$$
\mathrm{TCD}_{\mathrm{CON}}=\sqrt{\left(\mathrm{L}_{\mathrm{n}}^{*}-\mathrm{L}_{\mathrm{CON}}^{*}\right)^{2}+\left(\mathrm{a}_{\mathrm{n}}^{*}-\mathrm{a}_{\mathrm{CON}}^{*}\right)^{2}+\left(\mathrm{b}_{\mathrm{n}}^{*}-\mathrm{b}_{\mathrm{CON}}^{*}\right)^{2}}
$$

where: $n$ - products with flaxseed oil, and CON - control product.

$\mathrm{TCD}_{\mathrm{STOR}}=\sqrt{\left(\mathrm{L}_{\mathrm{D} 45}^{*}-\mathrm{L}_{\mathrm{D} 15}^{*}\right)^{2}+\left(\mathrm{a}_{\mathrm{D} 45}^{*}-\mathrm{a}_{\mathrm{D} 15}^{*}\right)^{2}+\left(\mathrm{b}_{\mathrm{D} 45}^{*}-\mathrm{b}_{\mathrm{D} 15}^{*}\right)^{2}}$

where: D45 - values et the end of storage, and D15 - values at the end of production.

Texture profile analysis was performed using a universal texture analyzer TAXP (Stable Micro System, Godalming, England) in the same manner as described by Stajić et al. [2014]. Hardness, adhesiveness, springiness, cohesiveness, and chewiness were measured and their values were processed using the available computer software. Eighteen readings were taken for each product, on D15 and D45.

\section{Sensory evaluation}

The evaluation of sensory attributes of sausages (D15 and D45) was conducted using small scale sensory consumer tests. Assessors group consisted of 40 untrained students from the Department of Animal Source Food Technology. All assessors regularly consume dry fermented sausages. A brief meeting was held before each assessment to explain the ballot and give instructions for evaluation. A numeric-descriptive scale with a nine-point system was used to evaluate colour, odour, taste, texture and overall acceptability of sausages ( 1 - extremely unacceptable, 9 - extremely acceptable).

Sample preparation was as follows: after removing the casing, sausages were cut into slices $c a .3 \mathrm{~mm}$ thick and served at room temperature on white, plastic plates randomly numbered with three-digit numbers. Three slices of each product were served. Assessors used water and unsalted crackers to cleanse their palate between samples.

\section{Statistical analysis}

To determine the differences between means of values (of all observed characteristics) within the same production day, one-way ANOVA was performed. Recipe formulation was assigned as the main effect (five levels). Tukey's HSD test was used to identify significant $(\mathrm{p}<0.05)$ differences between means. Student's t-test was used to examine the influence of storage on instrumental colour, instrumental texture and sensory characteristics. Calculations were done with software Statistica 12.5 (StatSoft, Inc., Tulsa, OK, USA).

\section{RESULTS AND DISCUSSION}

\section{Weight loss, proximate chemical composition and $\mathrm{pH}$ values}

The $\mathrm{pH}$ values (Table 2) during production and storage were similar $(p>0.05)$ in all products and within the values for the fermented sausages with added starter cultures. Initial values were from 5.83 (FXE) to $5.90(\mathrm{CON})$, while the minimum was achieved on D2 (5.18 (FXL) - 5.28 (FXA)), followed by a slight increase until D15 (5.26 (FXL) - 5.35 (FXA)) and during storage (5.29 (FXL) - 5.37 (FXA)). These values are similar with findings reported by other authors [Bloukas et al., 1997; Stajić et al., 2014; Triki et al., 2013].

During the production period, weight loss of products was the most intensive between D2 and D7 (Figure 2) when the recorded $\mathrm{pH}$ values were close to the isoelectric point of red meat proteins which is 5.2-5.3 [Cheng \& Sun, 2008]. However, on D7 the FXL sausage had a significantly lower $(p<0.05)$ weight loss relative to all other products (which had a similar weight loss, $\mathrm{p}>0.05)$. On D15, the FXI sausage had the highest weight loss $(382 \mathrm{~g} / \mathrm{kg})$ compared to CON sausage $(\mathrm{p}<0.05)$, while other products had a similar weight loss (339 $(\mathrm{CON})-354 \mathrm{~g} / \mathrm{kg}(\mathrm{FXA}))$.

The partial substitution of backfat with pre-treated flaxseed oil introduced a certain amount of water (used in oil pretreatments - Table 1) into the initial sausage mixture. This led to a higher moisture content in the modified products (except FXL sausage) relative to CON sausage, but significantly so $(p<0.05)$ only in FXE sausage (Table 3$)$. Water added with pre-treated oil did not change the weight loss pattern (Figure 2) since all products with added water had a similar 
TABLE 2. pH changes of dry fermented sausages with flaxseed oil preparations.

\begin{tabular}{|c|c|c|c|c|c|}
\hline \multirow{2}{*}{ Products } & \multicolumn{5}{|c|}{ Production time } \\
\hline & D0 & D2 & D7 & D15 & D45 \\
\hline $\mathrm{CON}$ & $5.90 \pm 0.07^{\mathrm{a}}$ & $5.19 \pm 0.04^{\mathrm{a}}$ & $5.25 \pm 0.05^{\mathrm{a}}$ & $5.31 \pm 0.04^{\mathrm{a}}$ & $5.34 \pm 0.04^{\mathrm{a}}$ \\
\hline FXL & $5.83 \pm 0.02^{\mathrm{a}}$ & $5.18 \pm 0.05^{\mathrm{a}}$ & $5.24 \pm 0.05^{\mathrm{a}}$ & $5.26 \pm 0.05^{\mathrm{a}}$ & $5.29 \pm 0.03^{\mathrm{a}}$ \\
\hline FXA & $5.86 \pm 0.01^{\mathrm{a}}$ & $5.28 \pm 0.05^{\mathrm{a}}$ & $5.28 \pm 0.05^{\mathrm{a}}$ & $5.35 \pm 0.06^{\mathrm{a}}$ & $5.37 \pm 0.04^{\mathrm{a}}$ \\
\hline FXI & $5.84 \pm 0.03^{\mathrm{a}}$ & $5.23 \pm 0.05^{\mathrm{a}}$ & $5.26 \pm 0.06^{\mathrm{a}}$ & $5.33 \pm 0.05^{\mathrm{a}}$ & $5.33 \pm 0.03^{\mathrm{a}}$ \\
\hline FXE & $5.83 \pm 0.03^{\mathrm{a}}$ & $5.19 \pm 0.05^{\mathrm{a}}$ & $5.23 \pm 0.01^{\mathrm{a}}$ & $5.28 \pm 0.05^{\mathrm{a}}$ & $5.32 \pm 0.02^{\mathrm{a}}$ \\
\hline
\end{tabular}

$\mathrm{a}, \mathrm{b}$ Values (mean $\pm \mathrm{SD}$ ) in the same column, with different letters are significantly different $(\mathrm{p}<0.05) ; \mathrm{CON}=\mathrm{Control}$ product; $\mathrm{FXL}=$ product with liquid flaxseed oil; FXA= product with flaxseed oil with alginate; FXI= product with flaxseed oil with soy protein isolate; FXE=treatment with encapsulated flaxseed oil; D0=production day 0 (raw, undried sausages); D2 and D7=production days 2 and 7, respectively; D15=production day 15 - end of drying process (dry fermented sausages); D45=production day 45 (dry fermented sausages after 30-day storage period).

weight loss on D2 and D7 relative to CON sausage. Differences in weight loss were found only on D15. The modified products (except FXL sausage) had a higher weight loss, significant $(p<0.05)$ only in the case of FXI relative to CON sausage (and FXL sausage). Weight loss in FXI sausage relative to FXE and FXA sausages was higher by about 3\%. Although not significant $(p>0.05)$, this may indicate lower capability of soy protein emulsion to keep water during the drying process of fermented sausages relative to alginate emulsion and encapsulated oil. Further research can be performed in this direction. This was similar to the results of our previous research [Stajić et al., 2014] where sausages with the same pre-treated grapeseed oil had 2-3\% higher weight loss relative to CON sausage and mutually similar weight loss. Bloukas et al. [1997] explained the significantly higher weight loss in fermented sausages, where backfat was partly replaced with olive oil pre-treated with SPI, by the higher amount of added water.

As a result of significantly lower weight loss, on D15, FXL sausage had a significantly higher $(\mathrm{p}<0.05)$ moisture content and a significantly lower $(\mathrm{p}<0.05)$ fat content
(Table 3) relative to all other products (which did not differ from each other), while protein content was similar in all products ( $>>0.05$ ). Bloukas et al. [1997] reported a similar effect of backfat substitution with liquid and PE (with SPI) olive oil - variants with liquid olive oil had a lower weight loss than control, while the ones with PE olive oil had a higher weight loss. A similar effect of liquid walnut oil addition a higher moisture content and a lower weight loss - was reported by Sánchez-Zapata et al. [2013]. Josquin et al. [2012] also reported a significantly higher moisture content in fermented sausages with backfat partially replaced with liquid fish oil. A possible explanation could be that liquid oil covers the pieces of meat in the mixture and prevents moisture loss during drying. By contrast, in a previous research, Stajić et al. [2014] reported a lower moisture content and no differences in weight loss in the sausages with liquid grapeseed oil. However, the findings were similar for the sausages with PE (with SPI) grapeseed oil. That research also found a significantly higher weight loss of sausages with encapsulated grapeseed oil and PE with alginate relative to CON sausage and no differences in moisture content.

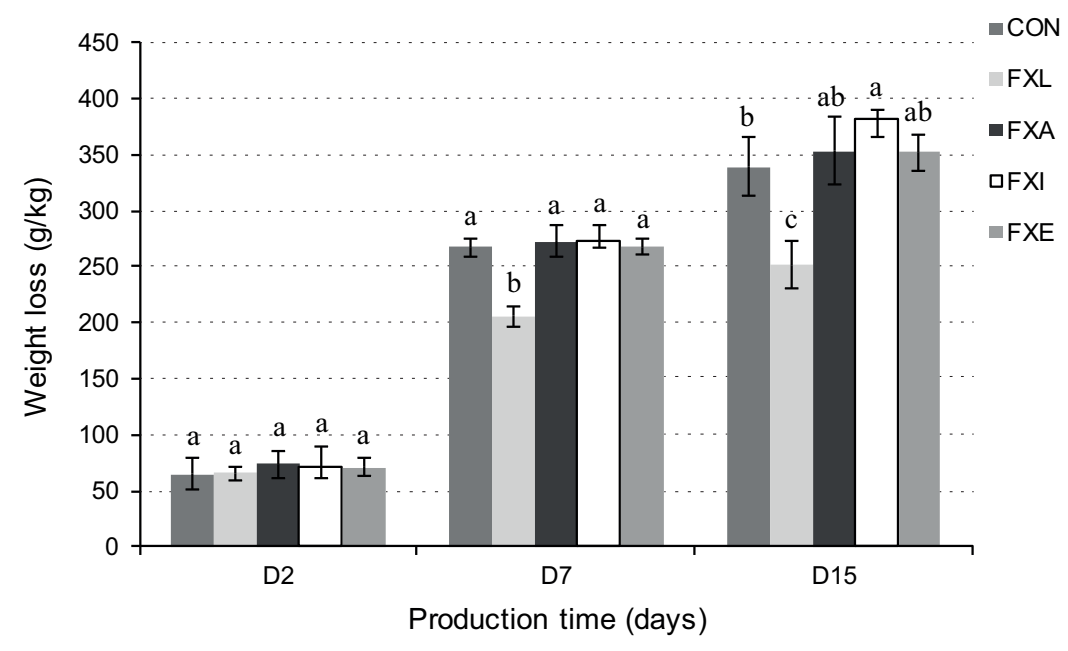

FIGURE 2. Weight loss during production period of modified dry-fermented sausages.

Different letters within the same production day indicates significant differences $(\mathrm{p}<0.05)$; $\mathrm{CON}=\mathrm{Control}$ product; $\mathrm{FXL}=$ product with liquid flaxseed oil; FXA= product with flaxseed oil with alginate; FXI=product with flaxseed oil with soy protein isolate; FXE=product with encapsulated flaxseed oil. 
TABLE 3. Moisture, fat and protein contents $(\mathrm{g} / \mathrm{kg})$ of dry fermented sausages with flaxseed oil preparations.

\begin{tabular}{|c|c|c|c|c|c|c|}
\hline \multirow{2}{*}{ Specification } & \multirow{2}{*}{$\begin{array}{l}\text { Production } \\
\text { time }\end{array}$} & \multicolumn{5}{|c|}{ Products } \\
\hline & & $\mathrm{CON}$ & FXL & FXA & FXI & FXE \\
\hline \multirow{3}{*}{ Moisture } & D0 & $563 \pm 16^{\mathrm{b}}$ & $567 \pm 2^{\mathrm{b}}$ & $579 \pm 5^{\mathrm{ab}}$ & $578 \pm 6^{\mathrm{ab}}$ & $589 \pm 9^{a}$ \\
\hline & D15 & $341 \pm 33^{\mathrm{ab}}$ & $411 \pm 10^{\text {ba }}$ & $350 \pm 17^{\mathrm{ab}}$ & $318 \pm 22^{\mathrm{ab}}$ & $340 \pm 15^{\mathrm{ab}}$ \\
\hline & D45 & $344 \pm 10^{\mathrm{b}}$ & $405 \pm 14^{\mathrm{a}}$ & $347 \pm 20^{b}$ & $315 \pm 21^{\mathrm{b}}$ & $334 \pm 17^{b}$ \\
\hline \multirow{3}{*}{ Fat } & D0 & $235 \pm 20^{\mathrm{a}}$ & $234 \pm 8^{a}$ & $229 \pm 20^{\mathrm{a}}$ & $231.66 \pm 10^{\mathrm{a}}$ & $237 \pm 12^{\mathrm{a}}$ \\
\hline & D15 & $361 \pm 6^{\mathrm{a}}$ & $314 \pm 9^{b}$ & $364 \pm 7^{\mathrm{a}}$ & $373 \pm 14^{\mathrm{a}}$ & $368 \pm 29^{a}$ \\
\hline & D45 & $353 \pm 22^{\mathrm{ab}}$ & $310 \pm 17^{b}$ & $364 \pm 20^{\mathrm{a}}$ & $370 \pm 21^{\mathrm{a}}$ & $375 \pm 29^{a}$ \\
\hline \multirow{3}{*}{ Protein } & D0 & $158 \pm 12^{\mathrm{a}}$ & $157 \pm 3^{\mathrm{a}}$ & $145 \pm 4^{\mathrm{a}}$ & $158 \pm 4^{\mathrm{a}}$ & $150 \pm 3^{\mathrm{a}}$ \\
\hline & D15 & $243 \pm 21^{\mathrm{a}}$ & $214 \pm 6^{\mathrm{a}}$ & $216 \pm 10^{\mathrm{a}}$ & $245 \pm 16^{\mathrm{a}}$ & $227 \pm 17^{\mathrm{a}}$ \\
\hline & D45 & $240 \pm 24^{\mathrm{ab}}$ & $213 \pm 8^{b}$ & $223 \pm 4^{\mathrm{ab}}$ & $252 \pm 19^{a}$ & $227 \pm 7^{\mathrm{ab}}$ \\
\hline
\end{tabular}

a, b Values (mean \pm SD) in the same row, with different letters are significantly different $(\mathrm{p}<0.05)$; $\mathrm{CON}=\mathrm{Control}$ product; $\mathrm{FXL}=$ product with liquid flaxseed oil; FXA= product with flaxseed oil with alginate; FXI= product with flaxseed oil with soy protein isolate; FXE=treatment with encapsulated flaxseed oil; D0=production day 0 (raw, undried sausages); D15=production day 15 - end of drying process (dry fermented sausages); D45= production day 45 (dry fermented sausages after 30-day storage period).

TABLE 4. Parameters of instrumental colour analysis of cross-section of dry fermented sausages with flaxseed oil preparations.

\begin{tabular}{|c|c|c|c|c|c|c|}
\hline \multirow{2}{*}{$\begin{array}{l}\text { Colour } \\
\text { parameters }\end{array}$} & \multirow{2}{*}{$\begin{array}{l}\text { Production } \\
\text { time }\end{array}$} & \multicolumn{5}{|c|}{ Products } \\
\hline & & $\mathrm{CON}$ & FXL & FXA & FXI & FXE \\
\hline \multirow{2}{*}{$\mathrm{L}^{*}$} & D15 & $51.04 \pm 2.55^{\mathrm{cA}}$ & $54.55 \pm 1.61^{\mathrm{bA}}$ & $54.48 \pm 1.22^{\mathrm{bA}}$ & $56.36 \pm 0.91^{\mathrm{aA}}$ & $53.86 \pm 1.59^{\mathrm{bA}}$ \\
\hline & D45 & $50.53 \pm 2.29^{\mathrm{cA}}$ & $52.44 \pm 1.36^{\mathrm{abB}}$ & $51.40 \pm 1.79^{\mathrm{bcB}}$ & $53.45 \pm 1.68^{\mathrm{aB}}$ & $51.50 \pm 1.11^{\mathrm{bcB}}$ \\
\hline \multirow{2}{*}{$a^{*}$} & D15 & $13.42 \pm 0.96^{\mathrm{abB}}$ & $12.86 \pm 0.82^{\mathrm{bB}}$ & $13.90 \pm 0.74^{\mathrm{aB}}$ & $13.77 \pm 0.60^{\mathrm{aB}}$ & $12.85 \pm 0.97^{\mathrm{bB}}$ \\
\hline & D45 & $14.27 \pm 1.07^{\mathrm{bcA}}$ & $13.58 \pm 0.78^{\mathrm{cA}}$ & $15.44 \pm 1.37^{\mathrm{aA}}$ & $14.67 \pm 1.09^{\mathrm{abA}}$ & $13.80 \pm 0.81^{\mathrm{bcA}}$ \\
\hline \multirow{2}{*}{$b^{*}$} & D15 & $7.96 \pm 0.48^{\mathrm{dA}}$ & $11.41 \pm 0.62^{\mathrm{cA}}$ & $12.20 \pm 0.66^{\mathrm{bA}}$ & $13.18 \pm 0.59^{\mathrm{aA}}$ & $11.26 \pm 0.55^{\mathrm{cA}}$ \\
\hline & D45 & $8.24 \pm 0.48^{\mathrm{dA}}$ & $11.52 \pm 0.35^{\mathrm{cA}}$ & $12.28 \pm 0.64^{\mathrm{bA}}$ & $13.02 \pm 0.51^{\mathrm{aA}}$ & $11.43 \pm 0.65^{\mathrm{cA}}$ \\
\hline \multirow{2}{*}{$\mathrm{C}^{*}$} & D15 & $15.61 \pm 0.89^{\mathrm{cB}}$ & $17.21 \pm 0.74^{\mathrm{bB}}$ & $18.51 \pm 0.75^{\mathrm{aB}}$ & $19.06 \pm 0.63^{\mathrm{aB}}$ & $17.10 \pm 0.65^{\mathrm{bB}}$ \\
\hline & D45 & $16.49 \pm 1.07^{\mathrm{cA}}$ & $17.82 \pm 0.74^{\mathrm{bA}}$ & $19.75 \pm 1.29^{\mathrm{aA}}$ & $19.62 \pm 1.05^{\mathrm{aA}}$ & $17.93 \pm 0.81^{\mathrm{bA}}$ \\
\hline \multirow{2}{*}{ h } & D15 & $30.74 \pm 2.17^{\mathrm{cA}}$ & $41.61 \pm 2.39^{\mathrm{abA}}$ & $41.27 \pm 1.98^{\mathrm{bA}}$ & $43.74 \pm 1.66^{\mathrm{aA}}$ & $41.31 \pm 3.05^{\mathrm{bA}}$ \\
\hline & D45 & $30.05 \pm 1.74^{\mathrm{dA}}$ & $40.35 \pm 1.42^{\mathrm{abA}}$ & $38.58 \pm 2.29^{\mathrm{cB}}$ & $41.65 \pm 1.73^{\mathrm{aB}}$ & $39.65 \pm 2.09^{\mathrm{bcA}}$ \\
\hline
\end{tabular}

a-d Values (mean \pm SD) in the same row, with different letters are significantly different $(p<0.05)$; ${ }^{\text {A, B }}$ Uppercase letters are used for comparing the samples considering the effect of storage. Values in the same column for the same property, with different superscripts are significantly different ( $<<0.05$ ); $\mathrm{CON}=$ Control product; $\mathrm{FXL}=$ product with liquid flaxseed oil; FXA= product with flaxseed oil with alginate; FXI=product with flaxseed oil with soy protein isolate; $\mathrm{FXE}=$ product with encapsulated flaxseed oil; $\mathrm{D} 0=$ production day 0 (raw, undried sausages); D15=production day 15 - end of drying process (dry fermented sausages); D45=production day 45 (dry fermented sausages after 30-day storage period).

\section{Instrumental colour analysis}

Some research indicate that a lower fat content leads to lower lightness and yellowness and higher redness [Soyer \& Ertas, 2007]. In this research, of all observed colour parameters (Table 4), on D15, redness was the only one for which no significant differences $(p>0.05)$ were recorded between CON sausage and the modified products. Furthermore, yellowness and hue angle (parameters which indicate a more yellow product), lightness and chroma were significantly higher $(\mathrm{p}<0.05)$ in all modified products relative to CON. This could indicate that oil colour characteristics and colour char- acteristics of pre-treatments had a greater impact on the colour of dry fermented sausages than the reduction of backfat in the amount used in this research.

Among the modified products, FXI stood out with the highest $(p<0.05) L^{*}, b^{*}$, and $h$ values. In our previous research [Stajić et al., 2014], we also recorded higher $(\mathrm{p}<0.05)$ $b^{*}$ and $h$ values of the product where backfat was partially substituted with PE (with SPI) grapeseed oil relative to CON and other modified products (sausages with grapeseed oil used as liquid, after encapsulation and pre-emulsified with alginate). However, other modified products had similar $b^{*}$ 
and $\mathrm{h}$ relative to $\mathrm{CON}$ sausage. This could be due to different colour parameters between grapeseed and flaxseed oil $-b^{*}$ values of flaxseed oil according to literature data are 70-100 [Choo et al., 2007; Teh \& Birch, 2013], while those of grapeseed oil are 12-30 [Giacomelli et al., 2006; Pardo et al., 2011]. Similarly to our research, Pelser et al. [2007] reported higher $b^{*}$ values when backfat was partially substituted with PE (with SPI) flaxseed oil. Alejandre et al. [2016] demonstrated that partial replacement of backfat with flaxseed oil gel emulsion (with carrageenan), depending on the amount of added oil, increased $L^{*}, a^{*}, b^{*}, C^{*}$, and $h$ values of fermented sausages. Beriain et al. [2011] reported higher $\mathrm{L}^{*}$ values and lower $a^{*}$ and $b^{*}$ values in chorizo with olive oil PE with alginate compared to the control chorizo. By contrast, $\mathrm{Mu}$ guerza et al. [2003] did not detect significantly different $\mathrm{L}^{*}, \mathrm{a}^{*}$, and $b^{*}$ values after the replacement of (15-30\%) backfat with PE (with SPI) soy oil.

The diversity of literature data indicates that the type of oil and/or the manner of its preparation can affect the value of instrumental colour analysis and should not be ignored in fermented sausage formulation.

After storage, FXA and FXE sausages had $\mathrm{L}^{*}$ values similar to CON sausage ( $p>0.05)$ (Table 4$)$, as was the case in our previous research [Stajić et al., 2014] for the same products with grapeseed oil. All products had significantly higher $(\mathrm{p}<0.05) \mathrm{a}^{*}$ and $\mathrm{C}^{*}$ values, while yellowness remained unchanged $(\mathrm{p}>0.05)$ (Table 4$)$. Hue angle was lower in all modified products, significantly so $(\mathrm{p}<0.05)$ in FXI and FXA sausages. Despite this, FXI sausage remained with the highest $\mathrm{h}$ values as on D15 (also with highest $b^{*}$ values), which is similar to the same product with grapeseed oil in our previous research [Stajić et al., 2014]. These results suggest that the use of SPI in oil pre-treatment as fat replacement in fermented sausages could be limited because of the potential increase in yellow tones in final products regardless of oil colour characteristics.

Values of $\mathrm{TCD}_{\mathrm{CON}}$ (Figure 3a) on D15 were within the 3-6 interval (except FXI sausage) which, according to Ramírez-Navas \& Rodríguez De Stouvenel [2012], indicates appreciable colour differences between the modified and CON sausages (values below 2.70 are not noticeable to the human eye). Values of $\mathrm{TCD}_{\mathrm{CON}}$ after storage (D45) were lower as a result of significantly $(\mathrm{p}<0.05)$ lower $\mathrm{L}^{*}$ values of all modified products, and were all within the 3-6 interval (3.37 (FXE) - 5.62 (FXI)).

Changes in colour parameters were almost similar in all products, hence the relations between products were similar as at the beginning of storage. Also, changes during storage were not so intensive, as indicated by the values of $\mathrm{TCD}_{\text {STOR }}$ (Figure $3 b$ ) which were slightly above 3 only in FXA and FXI sausages.

\section{Texture profile analysis}

The largest differences between products were obtained by texture profile analysis (Table 5), primarily in terms of hardness and chewiness.

Regarding hardness, on D15 and D45, all products differed significantly $(p<0.05)$ from each other (except CON and FXI sausages). Products with liquid (FXL sausage)


FIGURE 3. Total colour difference (TCD) of cross-section of modified dry fermented sausages: a) compared to $\mathrm{CON}\left(\mathrm{TCD}_{\mathrm{CON}}\right)$; b) after storage period $\left(\mathrm{TCD}_{\text {STOR }}\right)$.

Horizontal black line indicates visual detection limit; $\mathrm{CON}=$ Control product; $\mathrm{FXL}=$ product with liquid flaxseed oil; $\mathrm{FXA}=$ product with flaxseed oil with alginate; FXI = product with flaxseed oil with soy protein isolate; $\mathrm{FXE}=$ product with encapsulated flaxseed oil; D15=production day 15 - end of drying process (dry fermented sausages); D45=production day 45 (dry fermented sausages after 30-day storage period).

and encapsulated oil (FXE sausage) had significantly lower $(p<0.05)$ hardness relative to CON sausage and the other two products. These results correlate with our previous research in which grapeseed oil preparations were used [Stajić et al., 2014]. It is possible that liquid oil and the large number of microspheres prevent meat pieces from binding firmly during fermentation and ripening. Josquin et al. [2012] reported lower firmness in fermented sausages with liquid fish oil and attributed these results to the higher moisture content, which corresponds to our findings. The product with oil pre-treated with IPS (FXI sausage) had significantly higher $(p<0.05)$ hardness and chewiness relative to the other modified products, while the product with oil pre-treated with alginate (FXA sausage) had hardness and chewiness almost in the middle of the interval of the highest and lowest values (Table 5). These findings were consistent with the study in which grapeseed oil preparations were added to sausages [Stajić et al., 2014]. Contrary to our results, Muguerza et al. [2001] reported lower hardness and chewiness in fermented sausages with olive oil PE with SPI. Also, Pelser et al. [2007] reported lower firmness in fermented sausages with flaxseed oil PE with SPI. On the other hand, Bloukas et al. [1997] obtained higher values of firmness in fermented sausages with 
TABLE 5. Parameters of instrumental texture analysis of dry fermented sausages with flaxseed oil preparations.

\begin{tabular}{|c|c|c|c|c|c|c|}
\hline \multirow{2}{*}{$\begin{array}{l}\text { Texture } \\
\text { parameters }\end{array}$} & \multirow{2}{*}{$\begin{array}{l}\text { Production } \\
\text { time }\end{array}$} & \multicolumn{5}{|c|}{ Sausages } \\
\hline & & $\mathrm{CON}$ & FXL & FXA & FXI & FXE \\
\hline \multirow{2}{*}{$\begin{array}{l}\text { Hardness } \\
\text { (N) }\end{array}$} & D15 & $113.24 \pm 9.39^{\mathrm{aB}}$ & $62.28 \pm 10.58^{\mathrm{dB}}$ & $83.46 \pm 7.26^{\mathrm{bB}}$ & $108.34 \pm 7.59^{\mathrm{aB}}$ & $71.62 \pm 4.09^{\mathrm{cB}}$ \\
\hline & D45 & $133.00 \pm 8.14^{\mathrm{aA}}$ & $72.86 \pm 7.36^{\mathrm{dA}}$ & $96.36 \pm 5.65^{\mathrm{bA}}$ & $133.82 \pm 8.09^{\mathrm{aA}}$ & $81.62 \pm 4.92^{\mathrm{cA}}$ \\
\hline \multirow{2}{*}{$\begin{array}{l}\text { Adhesiveness } \\
(\mathrm{N} \times \mathrm{s})\end{array}$} & D15 & $-2.10 \pm 0.70^{\mathrm{aA}}$ & $-1.98 \pm 0.77^{\mathrm{aA}}$ & $-1.97 \pm 0.73^{\mathrm{aA}}$ & $-2.31 \pm 0.60^{\mathrm{aA}}$ & $-2.27 \pm 0.75^{\mathrm{aA}}$ \\
\hline & D45 & $-2.47 \pm 0.93^{\mathrm{aA}}$ & $-2.26 \pm 0.92^{\mathrm{aA}}$ & $-2.25 \pm 0.87^{\mathrm{aA}}$ & $-2.38 \pm 0.83^{\mathrm{aA}}$ & $-2.46 \pm 0.75^{\mathrm{aA}}$ \\
\hline \multirow{2}{*}{ Springiness } & D15 & $0.52 \pm 0.02^{\mathrm{cA}}$ & $0.54 \pm 0.03^{\text {ьв }}$ & $0.56 \pm 0.02^{\mathrm{aA}}$ & $0.56 \pm 0.02^{\mathrm{abA}}$ & $0.55 \pm 0.02^{\mathrm{abA}}$ \\
\hline & D45 & $0.52 \pm 0.02^{\mathrm{bA}}$ & $0.57 \pm 0.03^{\mathrm{aA}}$ & $0.57 \pm 0.02^{\mathrm{aA}}$ & $0.55 \pm 0.03^{\mathrm{aA}}$ & $0.56 \pm 0.02^{\mathrm{aA}}$ \\
\hline \multirow{2}{*}{ Cohesiveness } & D15 & $0.54 \pm 0.02^{\mathrm{bA}}$ & $0.59 \pm 0.02^{\mathrm{aA}}$ & $0.60 \pm 0.01^{\mathrm{aA}}$ & $0.59 \pm 0.01^{\mathrm{aA}}$ & $0.59 \pm 0.02^{\mathrm{aA}}$ \\
\hline & D45 & $0.52 \pm 0.01^{\mathrm{cB}}$ & $0.57 \pm 0.02^{\mathrm{aB}}$ & $0.57 \pm 0.01 \mathrm{~b}^{\mathrm{aB}}$ & $0.57 \pm 0.02^{\mathrm{aB}}$ & $0.55 \pm 0.02^{\mathrm{bB}}$ \\
\hline \multirow{2}{*}{ Chewiness } & D15 & $31.78 \pm 2.71^{\mathrm{bB}}$ & $20.01 \pm 3.71^{\mathrm{eB}}$ & $28.07 \pm 2.46^{\mathrm{cB}}$ & $35.95 \pm 1.67^{\mathrm{aB}}$ & $23.22 \pm 1.79^{\mathrm{dB}}$ \\
\hline & D45 & $35.46 \pm 2.49^{\mathrm{bA}}$ & $23.54 \pm 3.44^{\mathrm{dA}}$ & $30.97 \pm 2.10^{\mathrm{cA}}$ & $41.68 \pm 3.08^{\mathrm{aA}}$ & $25.18 \pm 2.00^{\mathrm{dA}}$ \\
\hline
\end{tabular}

${ }^{a-e}$ Values (mean \pm SD) in the same row, with different letters are significantly different $(p<0.05)$; , B Uppercase letters are used for comparing the samples considering the effect of storage. Values in the same column for the same property, with different superscripts are significantly different $(\mathrm{p}<0.05)$; $\mathrm{CON}=$ Control product; $\mathrm{FXL}=$ product with liquid flaxseed oil; FXA= product with flaxseed oil with alginate; FXI=product with flaxseed oil with soy protein isolate; $\mathrm{FXE}=$ product with encapsulated flaxseed oil; $\mathrm{D} 0=$ production day 0 (raw, undried sausages); D15=production day 15 - end of drying process (dry fermented sausages); D45=production day 45 (dry fermented sausages after 30-day storage period).

olive oil PE with SPI. Lorenzo et al. [2016] and Pelser et al. [2007] found that partial replacement of backfat with (micro)encapsulated flaxseed and fish oil led to higher firmness, and hardness and chewiness of sausages.

The same pattern was observed regarding springiness and cohesiveness - the control product had significantly $(\mathrm{p}<0.05)$ lower values relative to all modified products, and no differences $(p>0.05)$ were observed between the modified products (except between FXA and FXL sausages regarding springiness). No significant differences $(p>0.05)$ were observed in terms of adhesiveness either. These results are different from the ones obtained in our previous research [Stajić et al., 2014] in terms of the relations between $\mathrm{CON}$ and modified products, but they correlate with them regarding the relations between modified products - no differences between modified products were observed in terms of adhesiveness, springiness and cohesiveness. Lorenzo et al. [2016] and Muguerza et al. [2003] reported no significant changes regarding springiness and cohesiveness in fermented sausages with partial replacement of backfat with microencapsulated fish oil and PE (with SPI) soy oil.

After storage, hardness and chewiness of all products were significantly higher $(\mathrm{p}<0.05)$, the values of cohesiveness were significantly lower $(p<0.05)$, while no significant changes were observed in adhesiveness and springiness (except FXL sausage). These results differ from those of our previous research [Stajić et al., 2014], where sporadic changes of textural parameters were observed after storage of dry fermented sausages with grapeseed oil used as liquid, after encapsulation and pre-emulsified with alginate and soy protein isolate.

\section{Sensory evaluation}

Several highlights can be drawn from the sensory analysis results (Table 6). CON received the highest grades in terms of all observed sensory attributes, both before (D15) and after storage (D45), significantly $(\mathrm{p}<0.05)$ relative to FXL, FXE (except texture on D15) and FXI sausages. Assessors gave FXL sausage the lowest grades for all observed sensory attributes (D15 and D45) which were on the border of acceptability (mostly 5-6) and significantly lower $(\mathrm{p}<0.05)$ relative to $\mathrm{CON}$ and FXA sausages. Also, FXL sausage received significantly lower grades $(\mathrm{p}<0.05)$ relative to FXI sausage in terms of taste, texture, and overall acceptability (D15 and D45). Among the modified products, FXA sausage stood out with the highest grades, which were similar to CON sausage ( $p>0.05$, except colour D15 and overall acceptability D15 and D45). The 30-day storage period did not lead to significant changes in grades ( $p>0.05)$ scored for any of the observed sensory attributes, in any of the products (except taste FXE sausage). The sensory analysis grades confirm instrumental colour and texture results which indicate that the influence of oil characteristics and pretreatment should not be ignored.

In our previous research [Stajić et al., 2014], the product with grapeseed oil pre-treated with alginate was also indicated as possibly the most acceptable. Also, Beriain et al. [2011] reported good sensory characteristics (similar to control) of the product with olive oil pre-treated with alginate. Bloukas et al. [1997] and Josquin et al. [2012] also determined that replacing a part of backfat with liquid oil (olive and fish oil respectively) resulted in lower grades of the sensory characteristics of fermented sausages. By contrast, all modified products had significantly lower $(\mathrm{p}<0.05)$ colour grades in comparison to CON sausage, except FXA on D15 (Table 6), but it was close to the limit of relevance $(p=0.0594)$. This might be correlated with higher yellowness and hue angle of all modified products, which was not the case in our similar research with grapeseed oil [Stajić et al., 2014]. 
TABLE 6. Sensory evaluation of dry fermented sausages with flaxseed oil preparations.

\begin{tabular}{|c|c|c|c|c|c|c|}
\hline \multirow{2}{*}{$\begin{array}{l}\text { Sensory } \\
\text { attributes }\end{array}$} & \multirow{2}{*}{$\begin{array}{l}\text { Production } \\
\text { time }\end{array}$} & \multicolumn{5}{|c|}{ Products } \\
\hline & & $\mathrm{CON}$ & FXL & FXA & FXI & FXE \\
\hline \multirow{2}{*}{ Colour } & D15 & $8.45 \pm 0.75^{\mathrm{aA}}$ & $6.10 \pm 1.37^{\mathrm{bA}}$ & $7.73 \pm 1.01^{\mathrm{aA}}$ & $6.63 \pm 1.39^{\mathrm{bA}}$ & $6.45 \pm 1.41^{\mathrm{bA}}$ \\
\hline & D45 & $8.32 \pm 0.84^{\mathrm{aA}}$ & $5.94 \pm 1.58^{\mathrm{cA}}$ & $7.29 \pm 1.27^{\mathrm{bA}}$ & $6.29 \pm 1.36^{\mathrm{cA}}$ & $5.94 \pm 1.39^{\mathrm{cA}}$ \\
\hline \multirow{2}{*}{ Odour } & D15 & $7.73 \pm 0.91^{\mathrm{aA}}$ & $6.20 \pm 1.47^{\mathrm{cA}}$ & $7.25 \pm 1.32^{\mathrm{abA}}$ & $6.53 \pm 1.34^{\mathrm{bcA}}$ & $6.68 \pm 1.33^{\mathrm{bcA}}$ \\
\hline & D45 & $7.65 \pm 1.32^{\mathrm{aA}}$ & $5.68 \pm 1.61^{\mathrm{cA}}$ & $7.26 \pm 1.29^{\mathrm{abA}}$ & $6.32 \pm 1.55^{\mathrm{bcA}}$ & $6.29 \pm 1.34^{\mathrm{cA}}$ \\
\hline \multirow{2}{*}{ Taste } & D15 & $7.78 \pm 1.05^{\mathrm{aA}}$ & $5.65 \pm 1.67^{\mathrm{CA}}$ & $7.08 \pm 1.65^{\mathrm{abA}}$ & $6.83 \pm 1.36^{\mathrm{bA}}$ & $6.75 \pm 1.28^{\mathrm{bA}}$ \\
\hline & D45 & $8.03 \pm 1.29^{\mathrm{aA}}$ & $5.21 \pm 1.90^{\mathrm{dA}}$ & $7.09 \pm 1.50^{\mathrm{abA}}$ & $6.56 \pm 1.44^{\mathrm{bcA}}$ & $6.00 \pm 1.48^{\mathrm{cdB}}$ \\
\hline \multirow{2}{*}{ Texture } & D15 & $7.63 \pm 1.08^{\mathrm{aA}}$ & $5.40 \pm 1.58^{\mathrm{cA}}$ & $7.25 \pm 1.06^{\mathrm{abA}}$ & $7.13 \pm 1.34^{\mathrm{abA}}$ & $6.60 \pm 1.37^{\mathrm{bA}}$ \\
\hline & D45 & $8.06 \pm 1.10^{\mathrm{aA}}$ & $5.44 \pm 2.00^{\mathrm{dA}}$ & $7.35 \pm 1.30^{\mathrm{abA}}$ & $7.06 \pm 1.18^{\mathrm{bcA}}$ & $6.35 \pm 1.50^{\mathrm{cdA}}$ \\
\hline \multirow{2}{*}{$\begin{array}{l}\text { Overall } \\
\text { acceptability }\end{array}$} & D15 & $7.93 \pm 0.94^{\mathrm{aA}}$ & $5.50 \pm 1.45^{\mathrm{cA}}$ & $7.15 \pm 1.31^{\mathrm{bA}}$ & $6.95 \pm 1.18^{\mathrm{bA}}$ & $6.70 \pm 1.24^{\mathrm{bA}}$ \\
\hline & D45 & $8.15 \pm 1.02^{\mathrm{aA}}$ & $5.32 \pm 1.87^{\mathrm{dA}}$ & $7.09 \pm 1.50^{\mathrm{bA}}$ & $6.71 \pm 1.31^{\mathrm{bcA}}$ & $6.12 \pm 1.41^{\mathrm{cdA}}$ \\
\hline
\end{tabular}

${ }^{a-d}$ Values (mean $\left.\pm S D\right)$ in the same row, with different letters are significantly different $(p<0.05)$; ${ }^{A, B}$ Uppercase letters are used for comparing the samples considering the effect of storage. Values in the same column for the same property, with different superscripts are significantly different $(p<0.05)$; $\mathrm{CON}=$ Control product; $\mathrm{FXL}=$ product with liquid flaxseed oil; FXA= product with flaxseed oil with alginate; FXI=product with flaxseed oil with soy protein isolate; $\mathrm{FXE}=$ product with encapsulated flaxseed oil; $\mathrm{D} 0=$ production day 0 (raw, undried sausages); D15=production day 15 - end of drying process (dry fermented sausages); D45=production day 45 (dry fermented sausages after 30-day storage period).

Some other research also reported that fermented sausages with unchanged (or acceptable) sensory characteristics can be produced with partial replacement of backfat with pre-treated flaxseed oil [Alejandre et al., 2016; Pelser et al., 2007].

\section{CONCLUSIONS}

By partially replacing backfat with flaxseed oil, fermented sausages enriched with $n-3$ PUFA and with unchanged (or acceptable) sensory characteristics can be obtained subject to the proper choice of pre-treatment methods. Except for the liquid form, flaxseed oil used after encapsulation (FXE) and pre-emulsified with alginate (FXA) and soy protein isolate (FXI) did not influence the production process to a larger extent (pH change, weight loss, basic chemical composition). On the other hand, the influence of added oil and its pre-treatment on colour and texture parameters and sensory acceptability of dry fermented sausages should not be ignored. In that sense, flaxseed oil pre-treated with alginate has the greatest potential.

\section{ACKNOWLEDGEMENTS}

The authors would like to thank Mrs. Marija Stajić, MA for English proofreading.

\section{RESEARCH FUNDING}

The research was financed by the Ministry of Education, Science and Technological Development, Republic of Serbia, projects III-46009.

\section{CONFLICT OF INTERESTS}

Authors declare no conflict of interests.

\section{REFERENCES}

1. Alejandre M., Poyato C., Ansorena D., Astiasarán, I., Linseed oil gelled emulsion: A successful fat replacer in dry fermented sausages. Meat Sci., 2016, 121, 107-113.

2. Beriain M.J., Gómez I., Petri E., Insausti K., Sarriés M.V., The effects of olive oil emulsified alginate on the physico-chemical, sensory, microbial, and fatty acid profiles of low-salt, inulin-enriched sausages. Meat Sci., 2011, 88, 189-197.

3. Bloukas J.G., Paneras E.D., Fournitzis G.C., Effect of replacing pork backfat with olive oil on processing and quality characteristics of fermented sausages. Meat Sci., 1997, 45, 133-144.

4. Bolumar T., Toepfl S., Heinz V., Fat reduction and replacement in dry-cured fermented sausage by using high pressure processing meat as fat replacer and olive oil. Pol. J. Food Nutr. Sci., 2015, 65, 175-182.

5. Bozkurt H., Bayram M., Colour and textural attributes of sucuk during ripening. Meat Sci., 2006, 73, 344-350.

6. Cheng, Q., Sun, D.W., Factors affecting the water holding capacity of red meat products: a review of recent research advances. Crit. Rev. Food. Sci. Nutr., 2008, 48, 137-159.

7. Choo W.-S., Birch J., Dufour J.-P., Physicochemical and quality characteristics of cold-pressed flaxseed oils. J. Food Compos. Anal., 2007, 20, 202-211.

8. Decker E.A., Park Y., Healthier meat products as functional foods. Meat Sci., 2010, 86, 49-55.

9. Delgado-Pando G., Cofrades S., Ruiz-Capillas C., Teresa Solas M., Jiménez-Colmenero F., Healthier lipid combination oil-in- 
water emulsions prepared with various protein systems: An approach for development of functional meat products. Eur. J. Lipid Sci. Technol., 2010, 112, 791-801.

10. Doyon M., Labrecque J., Functional Foods: A conceptual definition. Br. Food J., 2008, 110, 1133-1149.

11. Giacomelli L., Mattea M., Ceballos C., Analysis and characterization of edible oils by chemometric methods. J. Am. Oil Chem. Soc., 2006, 83, 303-308.

12. Gogus U., Smith C., n-3 Omega fatty acids: A review of current knowledge. Int. J. Food Sci. Technol., 2010, 45, 417-436.

13. ISO 1443:1973. Meat and Meat Products. Determination of Total Fat Content, International Organization for Standardization, Geneva, Switzerland.

14. ISO 937:1978. Meat and Meat Products. Determination of Nitrogen Content, International Organization for Standardization, Geneva, Switzerland.

15. ISO 1442:1997. Meat and Meat Products. Determination of Moisture Content, International Organization for Standardization, Geneva, Switzerland.

16. Josquin N.M., Linssen J.P.H., Houben J.H., Quality characteristics of Dutch-style fermented sausages manufactured with partial replacement of pork back-fat with pure, pre-emulsified or encapsulated fish oil. Meat Sci., 2012, 90, 81-86.

17. Kaur S., Das M., Functional foods: An overview. Food Sci. Biotechnol., 2011, 20, 861-875.

18. Lorenzo J.M., Munekata P.E.S., Pateiro M., Campagnol P.C.B., Domínguez R., Healthy Spanish salchichón enriched with encapsulated $n-3$ long chain fatty acids in konjac glucomannan matrix. Food Res. Int., 2016, 89, 289-295.

19. Muguerza E., Ansorena D., Astiasarán I., Improvement of nutritional properties of Chorizo de Pamplona by replacement of pork backfat with soy oil. Meat Sci., 2003, 65, 1361-1367.

20. Muguerza E., Gimeno O., Ansorena D., Bloukas J.G., Astiasarán I., Effect of replacing pork backfat with pre-emulsified olive oil on lipid fraction and sensory quality of Chorizo de Pamplona a traditional Spanish fermented sausage. Meat Sci., 2001, 59, 251-258.

21. Olmedilla-Alonso B., Jiménez-Colmenero F., Sánchez-Muniz F.J., Development and assessment of healthy properties of meat and meat products designed as functional foods. Meat Sci., 2013, 95, SI, 919-930.

22. Pardo J.E., Rubio M., Pardo A., Zied D.C., Álvarez-Ortí M., Improving the quality of grape seed oil by maceration with grinded fresh grape seeds. Eur. J. Lipid Sci. Technol., 2011, 113, 1266-1272.
23. Pelser W.M., Linssen J.P.H., Legger A., Houben J.H., Lipid oxidation in $\mathrm{n}-3$ fatty acid enriched Dutch style fermented sausages. Meat Sci., 2007, 75, 1-11.

24. Ramírez-Navas J.S., Rodríguez De Stouvenel A., Characterization of Colombian quesillo cheese by spectrocolorimetry. Vitae, 2012, 19, 178-185.

25. Sánchez-Zapata E., Díaz-Vela J., Pérez-Chabela M., Pérez-Alvarez J., Fernández-López J., Evaluation of the effect of tiger nut fibre as a carrier of unsaturated fatty acids rich oil on the quality of dry-cured sausages. Food Bioprocess Technol., 2013, 6, 1181-1190.

26. Siró I., Kápolna E., Kápolna B., Lugasi A., Functional food. Product development, marketing and consumer acceptance A review. Appetite, 2008, 51, 456-467.

27. Soyer A., Ertas A.H., Effects of fat level and storage time on lipid and color stability of naturally fermented Turkish sausages (sucuk). J. Muscle Foods, 2007, 18, 330-340.

28. Stajić S., Stanišić N., Tomović V., Petričević M., Stanojković A., Radović Č., Gogić M., Farb- und Texturveränderungen während der Lagerung bei Sremska, einer traditionellen serbischen Rohwurst. Fleischwirtschaft, 2017, 8, 103-107 (in German, English abstract).

29. Stajić S., Živković D., Tomović V., Nedović V., Perunović M., Kovjanić N., Lević S., Stanišić N., The utilisation of grapeseed oil in improving the quality of dry fermented sausages. Int. J. Food Sci. Technol., 2014, 49, 2356-2363.

30. Teh S.-S., Birch J., Physicochemical and quality characteristics of cold-pressed hemp, flax and canola seed oils. J. Food Compos. Anal., 2013, 30, 26-31.

31. Trautwein E., n-3 Fatty acids - physiological and technical aspects for their use in food. Eur. J. Lipid Sci. Technol., 2001, 103, $45-55$.

32. Triki M., Herrero A.M., Rodríguez-Salas L., Jiménez-Colmenero F., Ruiz-Capillas C., Chilled storage characteristics of low-fat, n-3 PUFA-enriched dry fermented sausage reformulated with a healthy oil combination stabilized in a konjac matrix. Food Contr., 2013, 31, 158-165.

33. Zhang W., Xiao S., Samaraweera H., Lee E.J., Ahn D.U., Improving functional value of meat products. Meat Sci., 2010, 86, SI, 15-31.

Submitted: 5 October 2017. Revised: 28 March and 11 June 2018. Accepted: 5 July 2018. Published on-line: 17 August 2018. 